\title{
Phenomenological perspectives on self-care in aging
}

This article was published in the following Dove Press journal:

Clinical Interventions in Aging

28 May 2013

Number of times this article has been viewed

\section{Olle Söderhamn \\ Center for Caring Research- Southern Norway, Faculty of Health and Sport Sciences, University of Agder, Grimstad, Norway}

\begin{abstract}
Self-care is a central concept in health care and may be considered as a means to maintain, restore, and improve one's health and well-being. When performed effectively, self-care contributes not only to human functioning but also to human structural integrity and human development (ie, to a dynamic and holistic state of health). Self-care as a clinical concept is relevant for health care professionals, and it should be meaningful to investigate it at a philosophical level and to further elaborate upon this concept. The aim of this article is to discuss and elaborate upon a phenomenological perspective on self-care in aging that is relevant for the health sciences. Self-care may be preliminarily regarded as a fundamental perspective for the conscious older individual, and as a way of being in the world with both the objective body and with the lived body. The lived body is the personal center of perception and the field of action, and it is also the center of self-care. The potentiality or ability for self-care activity and self-care activity itself are structures given to perception, with self-care ability as an integral part of the lived body. The actualization of self-care ability comes about through a certain meaning, which can be regarded as an important driving force. It is constituted by communication, a healthy lifestyle, and by building meaning and socializing. Successful selfcare involves having contacts with the health care system, being conscious of a sound lifestyle, being physically and mentally active, being engaged, having social contacts with family and others, as well as being satisfied, positive, and being able to look forward. One fundamental cornerstone is serenity on behalf of the individual. Self-care can facilitate transitions, and it may also be an outcome of transitions.
\end{abstract}

Keywords: ability, activity, lived body, older people, phenomenology

\section{Introduction}

Self-care is a central concept in health care, and it may be regarded as the means through which to maintain, restore, and improve health and well-being. ${ }^{1}$ It could, however, also be considered on a more general level, where a fundamental goal for human beings should be to reach a high degree of self-care agency in order to obtain good health and a good life. ${ }^{1}$ Orem ${ }^{2}$ states that self-care that is performed effectively contributes not only to human functioning, but also to human structural integrity and human development (ie, to a dynamic and holistic state of health). When choosing a holistic view of health, where vital goals, ${ }^{3}$ expanding consciousness, ${ }^{4}$ and human becoming, ${ }^{5}$ for example, are central for understanding self-care, it should be meaningful to investigate the self-care concept at a philosophical level and also to further elaborate upon it.

Life itself bears possibilities, and living is to be interpreted according to its relational sense as caring. To live means to care for one's daily life,${ }^{6}$ and this implies that 
self-care may be considered as a fundamental category in life. Caring promotes health, ${ }^{7,8}$ and caring can be seen as helping other persons to grow. ${ }^{9}$ To care for oneself is to help oneself to grow and to change. Health as expanding consciousness, ${ }^{4}$ human becoming, ${ }^{5}$ or reaching vital goals in life is, thus, a possible outcome of self-care. ${ }^{3}$

In a synthesis of theoretical and empirical literature related to self-care and health promotion in aging, Leenerts et $\mathrm{al}^{10}$ formulated a model of self-care in which the complexities of aging were thought to be moderated by partnerships between health care providers and clients. Such partnerships are based on mutual respect, and caring and may also underlie the structure for health care interventions to promote self-care abilities and practices to foster health. This is conceptualized by Orem ${ }^{2}$ as compensatory care, which can be complete or partial. Outcomes can, according to Leenerts et al, ${ }^{10}$ include connectedness, transcendence, resource use, and well-being.

\section{Aim}

The aim of this article was to discuss and elaborate upon a phenomenological perspective on self-care in aging that is relevant for the health sciences.

\section{Self-care}

\section{Some phenomenological views}

An alternative to the traditional and predominant worldview in health care is viewed in the man-environment simultaneity paradigm. ${ }^{11,12}$ The beliefs set forth in the simultaneity paradigm are that human beings are more than and different from the sum of their parts. They are open beings, free to choose in mutual interchanges with the environment. Health is a set of value priorities and a process of growth or becoming, and these are experienced by the individual and are only possibly described by the individual. The research tradition in this paradigm is qualitative in orientation, and is more specifically phenomenological. ${ }^{13}$

In an attempt to situate self-care within a phenomenological paradigm, Söderhamn ${ }^{1}$ has claimed that there is a dialectical relation between self-care ability as potentiality for self-care activity and self-care activity itself, and that both may be regarded as structures given to perception. Self-care ability was also considered as an integral part of the lived body; the actualization of this ability may possibly come about through a certain meaning.

There are examples of phenomenological research studies about self-care in the research literature that indicate the importance of transitions and the sense of self. ${ }^{14-16}$
Self-care can facilitate transitions, and it may also be an outcome of transitions.

\section{Transition and being}

Being of things in its most general and indeterminate sense is by Maritain ${ }^{17}$ referred to from the standpoint of action (ie, in reference to what they do). The natural behavior of things, as grasped by the senses and consciousness, is that things change; for example, a plant grows, what was living dies one day, and a bird flies. Although it may be hard to explain scientifically, most people know by experience what change and motion consist of; if there is change, there is also a transition from one mode of being to another. For a transition to exist, there must be something that undergoes this change, as well as something that is the subject of change. Thus, identity must exist prior to change, and change cannot occur without a subject that can be changed, and which is some particular thing before it changes. When a thing shall change, it has a particular identity; it is not yet that particular thing it is destined to become, but it possesses the means to be it (ie, it can be it). ${ }^{17}$

Being is central in Sartre's phenomenological ontology, ${ }^{18}$ and being is in-itself (ie, a nonconscious being). For-itself, or a conscious being, is what Sartre calls the nihilation of in-itself. A third modality is being-for-others where the self exists outside as an object for others.

Between being and not being there is the power of being or potentiality. ${ }^{17}$ This concept was already used by Aristotle, ${ }^{19}$ who indicated that nature first provides us with potentialities and later effects their actualization. Potentiality is the capacity of an object to pass from one state to another. A person who is asleep is potentially a person who is awake; this means that $\mathrm{X}$ can change to $\mathrm{Y}$ because some conditions of Y-ness are already inherent in $\mathrm{X} .{ }^{20}$ When operating within a selfcare frame of reference, potentiality may be conceptualized as self-care ability and considered as a necessary condition for self-care activities. When self-care ability is exercised, the result is self-care activity. ${ }^{1}$

When a human being undergoes a transition from one being to another, self-care activities can facilitate this transition. This refers to the idea that transition is a passage from one life phase, condition, or status to another, and it is both a process and an outcome of complex person-environment interactions. Health care professionals deal with people who are anticipating transition, experiencing transition, or completing the act of transition. ${ }^{21,22}$ Transitions are primarily developmental, situational, or health/illness events. ${ }^{22}$ Good health and enhanced self-care ability may be considered as an outcome variable in a positive transition. 


\section{Being human}

Consciousness is a consciousness of the world, and the body is the center of consciousness. We come across bodies either as objects or subjects. Moreover, the body can be a body for-me and a body for-others. ${ }^{18}$ We can encounter bodies as being-in-themselves - either our own bodies or the bodies of others - as physical objects and as physiological and anatomical bodies. We also encounter bodies of others as meaningful objects in special situations. Our own body is the lived body, the body-for-itself. This body subject is my center of perception and field of action. ${ }^{23}$

Thus, the body can be either a subject or an object, and there is a strong connection between embodiment and being-in-the-world. The objective body of the biological and medical sciences has a location in objective time and space. We look upon it in a detached and third-person way. ${ }^{24}$ Disease is related to the objective body, and illness is the lived experience of having a disease, which is related to the subjective body and is a particular way of being-in-the-world. ${ }^{25}$

\section{Self-care ability and its actualization}

In an empirical study among older home-dwelling persons, Söderhamn ${ }^{16}$ found that the structure of self-care ability among older people entailed (1) being present to the opportunity to act on certain perceived influences on the body; and (2) being alone or receiving support from somebody else to be able to bring about a change in attitude towards one's personal lifestyle or life situation. The meaning of actualizing this ability into self-care activity was interpreted as self-realization or self-transcendence. The actualization of self-care ability comes about through this meaning, ${ }^{1,16}$ which may be regarded as an important driving force.

It is possible that people think that they possess self-care ability, but actually they do not have this ability. They believeand in a way, lie to themselves - that they have the resources to do self-care activities (ie, that they can and want, under prevailing circumstances, care for themselves in order to maintain, restore, or improve their health and well-being). ${ }^{26}$

When people lie to themselves, the phenomenon of selfdeception or bad faith, in the words of Sartre, ${ }^{18}$ is present. Bad faith can be described and motivated by the anguish that is our consciousness of our ambiguous freedom. Self-deception is paradoxical and requires that a person both believes something and does not believe it. ${ }^{23}$ We deal with human reality as a being, which is what it is not and which is not what it is. ${ }^{18}$

Leenerts et $\mathrm{l}^{10}$ found in their meta-analysis that self-care ability contains the components consciousness, independence, problem solving, relating, and reconciliation. Self-care activity (ie, the actualization of self-care ability), ${ }^{1}$ is constituted by communication, a healthy lifestyle, and by building meaning and socializing. ${ }^{10}$ It has also been shown in a group of older people with high sense of coherence that successful self-care involves having, when needed, contact with the health care system, being conscious of a sound lifestyle, being physically and mentally active, being engaged, having social contacts with family and/or others, being satisfied and positive, and by looking forward. ${ }^{27}$

The bridge between self-care ability and self-care activity may be interpreted as self-realization and/or selftranscendence. ${ }^{16}$ These two may also be considered as necessary motivational driving forces for the individual, and self-deception or bad faith may not be regarded as sufficient for actualizing the individual's self-care ability into self-care activity. The antithesis of bad faith is serenity, ${ }^{18}$ and serenity on behalf of the individual should be considered as one of the fundamental cornerstones in self-care.

A study among individuals between 55 and 65 years of age indicated that when self-care is actualized in connection with the anticipated transition into later life, there were opportunities, expectations, wishes, concerns, and worries related to this transition. ${ }^{28}$ Self-care, in connection with this idea, depended on motivating and demotivating factors. Autonomy and mature dependence were positive driving forces, and supporting autonomy should be a way of facilitating the transition into retirement and later life. ${ }^{28}$

\section{Perspectives}

When viewing self-care in aging within a phenomenological frame of reference, previous empirical studies indicated that it may be preliminarily regarded as a fundamental perspective for the conscious older individual, and as a way of being-in-the-world with both the objective body and the lived body involved. ${ }^{10,14-16,26-28}$ The lived body as the personal center of perception and field of action is also the center of self-care.

The potentiality for self-care activity and self-care activity itself are structures given to perception, with self-care ability as an integral part of the lived body. Self-care activity is an intentional act directed both to the objective and lived body and is characterized by connectedness and transcendence, resource use, and well-being. The actualization of self-care ability comes about through a certain meaning, which can be regarded as an important driving force. It is constituted by communication, a healthy lifestyle, and through building meaning and socializing. 
Successful self-care involves having contacts with the health care system, being conscious of a sound lifestyle, being physically and mentally active, being engaged, having social contacts with family and others, and being satisfied and positive and looking forward. One fundamental cornerstone is serenity on behalf of the individual. Self-care can facilitate transitions, and it may also be an outcome of transitions.

Health care professionals, informal caregivers, family, and friends are important in supporting older individuals in their self-care. On a societal level, special community-based health care centers, voluntary centers, and other social meeting places can be engines of support for older people with respect to their self-care. Although much common sense knowledge is valuable within the concept of self-care, it should be noted that professional knowledge within health, medicine, and caring is important for providing efficient self-care support. Motivational support and knowledge about psychology and pedagogy are other important areas among both formal and informal caregivers in order to "sell in" the idea of self-care and facilitate the actualization from selfcare ability into self-care activity. This knowledge is also important in order to identify and prevent self-deception in relation to self-care. Older people with illnesses and diseases may be less susceptible to motivate, which also demands high-level competency about older people.

\section{Disclosure}

The author reports no conflicts of interest in this work.

\section{References}

1. Söderhamn O. Self-care activity as a structure: a phenomenological approach. Scand J Occup Ther. 2000;7:183-189.

2. Orem DE. Nursing: Concepts of Practice. 6th ed. St Louis, MO: Mosby Year Book; 2001.

3. Nordenfelt LY. On the Nature of Health. An Action-Theoretic Approach. Second Revised and Enlarged Edition. Dordrecht, The Netherlands: Kluwer Academic Publishers; 1995.

4. Newman MA. Health as Expanding Consciousness. 2nd ed. New York, NY: National League for Nursing Press; 1999.

5. Parse RR. The Human Becoming School of Thought. A Perspective for Nurses and Other Health Professionals. Thousand Oaks, CA: Sage Publications Inc; 1998.
6. Heidegger M. Phenomenological Interpretations of Aristotle. Initiation Into Phenomenological Research. (Translation by Richard Rojcewicz of lectures presented at the University of Freiburg, winter 1921-1922.) Bloomington and Indianapolis: Indiana University Press; 2001.

7. Watson J. Nursing: The Philosophy and Science of Caring. Boulder, CO: Colorado Associated University Press; 1985.

8. Watson J. Nursing: Human Science and Human Care. A Theory for Nursing. New York, NY: National League for Nursing; 1988.

9. Mayerhoff M. On Caring. New York, NY: Harper Perennial; 1990.

10. Leenerts MH, Teel CS, Pendleton MK. Building a model of self-care for health promotion in aging. J Nurs Scholarsh. 2002;34(4):355-361.

11. Parse RR. Paradigms and theories. In: Parse RR, editor. Nursing Science: Major Paradigms, Theories, and Critiques. Philadelphia, PA: W.B. Saunders Company; 1987:1-12.

12. Cody WK. About all those paradigms: many in the universe, two in nursing. Nurs Sci Q. 1995;8(4):144-147.

13. Parse RR. Section overview. The simultaneity paradigm. In: Parse RR, editor. Nursing Science: Major Paradigms, Theories, and Critiques. Philadelphia, PA: WB Saunders Company; 1987:135-138.

14. Anderson JM. Immigrant women speak of chronic illness: the social construction of the devalued self. J Adv Nurs. 1991;16(6): $710-717$.

15. Fex A, Flensner G, Ek AC, Söderhamn O. Health-illness transition among persons using advanced medical technology at home. Scand $J$ Caring Sci. 2011;25(2):253-261.

16. Söderhamn O. Self-care ability in a group of elderly Swedish people: a phenomenological study. J Adv Nurs. 1998;28(4):745-753.

17. Maritain J. An Introduction to Philosophy. London, UK: Continuum, 2005.

18. Sartre JP. Being and Nothingness. An Essay on Phenomenological Ontology. London, UK: Routledge; 2003.

19. Aristotle. The Ethics of Aristotle. The Nicomachean Ethics. (Translated by JAK. Thomson. Revised with notes and appendices by HTredennick.) London: Penguin Books Ltd; 1976.

20. Luce JV. An Introduction to Greek Philosophy. London, UK: Thames and Hudson Ltd; 1992.

21. Meleis AI, Trangenstein PA. Facilitating transitions: redefinition of the nursing mission. Nurs Outlook. 1994;42(6):255-259.

22. Meleis AI. Theoretical Nursing: Development and Progress. 4th ed. Philadelphia, PA: Lippincott Williams \& Wilkins; 2007.

23. Morris KJ. Sartre. Oxford, UK: Blackwell Publishing; 2008.

24. Matthews E. Merleau-Ponty. A Guide for the Perplexed. London, UK: Continuum; 2006.

25. Tooms SK. The Meaning of Illness: A Phenomenological Account of the Different Perspectives of Physician and Patient. Dordrecht, The Netherlands: Kluwer Academic Publishers; 1993.

26. Söderhamn O, Ek AC, Pörn I. The self-care ability scale for the elderly. Scand J Occup Ther. 1996;3:68-78.

27. Söderhamn U, Dale B, Söderhamn O. Narrated lived experiences of self-care and health among rural-living older persons with a strong sense of coherence. Psychol Res Behav Manag. 2011;4:151-158.

28. Söderhamn O, Skisland A, Herrman M. Self-care and anticipated transition into retirement and later life in a Nordic welfare context. J Multidiscip Healthc. 2011;4:273-279.
Clinical Interventions in Aging

\section{Publish your work in this journal}

Clinical Interventions in Aging is an international, peer-reviewed journal focusing on evidence-based reports on the value or lack thereof of treatments intended to prevent or delay the onset of maladaptive correlates of aging in human beings. This journal is indexed on PubMed Central, MedLine, the American Chemical Society's 'Chemical Abstracts Ser-

\section{Dovepress}

vice' (CAS), Scopus and the Elsevier Bibliographic databases. The manuscript management system is completely online and includes a very quick and fair peer-review system, which is all easy to use. Visit $\mathrm{http}: / /$ www.dovepress.com/testimonials.php to read real quotes from published authors. 